\title{
フェノール樹脂繊維 一 カイノールー
}

\author{
Phenolic Resin Fiber - Kynol ${ }^{T M}-$
}

木 村 勝 ·高 瀬徹

\section{1. はじめに}

米国 Carborundum 社により、1968 年フェノール樹脂 が初めて実験室規模で繊維化され、カイノールと命名され た。一般名をノボロイド繊維と呼ばれるこのフェノール樹 脂繊維開発の背景にはNASA の要望による安価な炭素繊 維の供給ということがあった。フェノール樹脂はその原料 価格が比較的安く、かつこのフェノール樹脂から得られる カイノールは炭素含有率が約 $76 \%$ と高く、炭素化した場 合の炭素残留率の高い事が期待され、結果的に安価な炭素 瀻維の供給が可能と考えられたからである。実際にこのカ イノールから得られる炭素繊維の炭素残留率は 50 ～60\% と炭素纎維の中でも比較的高い部類に入る。

当初はその当時開発が始められていたスペースシャトル の構造材の一部として検討されていたが、カイノールから 得られた炭素繊維は機械的強度が不足していた為に、目的 を達成する事が出来なかった。当時のカイノール炭素化技 術が未熟であった事も一因であろうが、元来フェノール樹 脂の炭素化物は、いわゆるハードカーボンに属するもので あり、カイノールからの炭素瀻維も配向性のないアモル ファス炭素である事が主原因であったようである。

NASA 向け炭素瀻維用としての開発は不成功に終わっ たものの、そのプリカーサーであるフェノール樹脂繊維、 すなわちカイノールには防炎性という大きな特長があり、 これに着目して研究が続行された。しかし、米国で発明さ れたこのカイノールも工業的生産技術を完成させるにはい たらず、その開発は用途開発も含めて、1972 年より日本 に打いて進められた。当初はカイノールの防炎性、難燃性 を生かし、消防服、安全作業服などの防災安全テキスタイ ルの分野に力が注がれた。その後はカイノールの有する、 すなわちフェノール樹脂が本来有する耐熱性、耐薬品性、 非溶融性などの特長が評価され産業用資材として用途開発 され、またカイノールからの炭素紪維がアモルファス炭素

\section{MASARU KIMURA}

群栄化学工業株式会社 環境・エネル

ギーユニット

テ370-0032 群馬県高崎市宿大類700番地

Tel :027-350-1875 Fax:027-353-1845

E-mail:m-kimura@gunei-chemical.co.jp

〈専門〉炭素材料化学(炭素繊維・活性 炭)、有機化学 (熱硬化性樹脂)
である事を逆手にとり、構造材以外の炭素繊維や活性炭素 繊維として開発が続けられた。それと同時に工業的生産技 術の研究開発も進み、1986 年から本格的な工業生産が開 始された。現在このカイノール繊維は、原料となるフェノー ル樹脂を含め、世界で唯一、群栄化学工業(株で生産されて いる。

\section{2. 製造法と構造}

カイノールはフェノール樹脂を溶融紡糸した後、硬化反 応をさせて得られる三次元網目構造を有するアモルファス の繊維である。一般的な繊維が 30 ～80\% の結晶化度を有 しているのに比べればカイノールは極めて特異な繊維とい えよう。図 1 にカイノールの製造工程図を示す。まずフェ ノールにホルムアルデヒドを酸性触媒下において反応させ ると、分子量 1000 程度のノボラック型フェノール樹脂が 得られる。得られたノボラック樹脂の推定化学構造図を

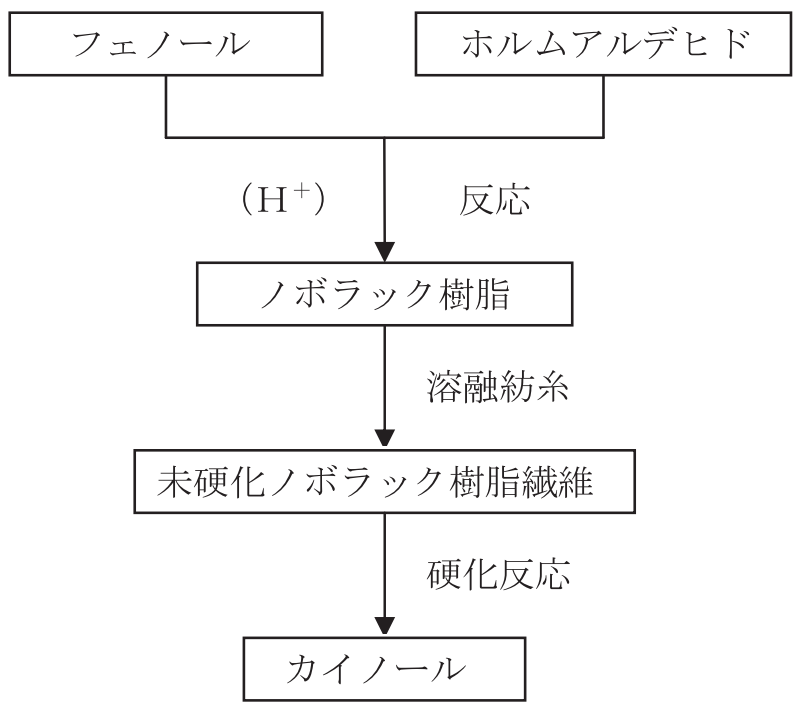

図 1 カイノール製造工程図

TORU TAKASE

群栄化学工業株式会社＼cjkstart第二事業部門

環境・エネルギーユニット＼cjkstart営業

厂530-0012 大阪市北区芝田 2-2-17

Tel : 06-6376-1600 Fax:06-6375-0829

E-mail : t-takase@gunei-chemical.co.jp 


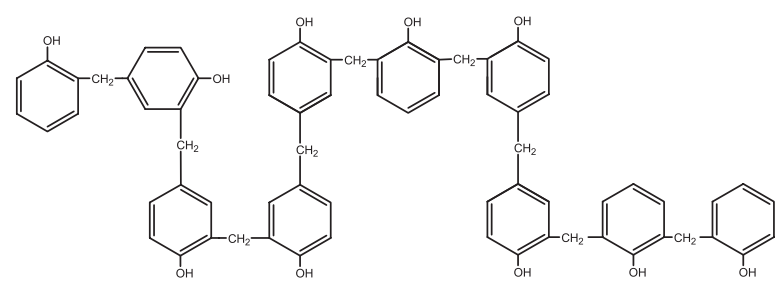

図 2 ノボラック樹脂推定化学構造

図 2 に示す。この樹脂を溶融紡糸すると未硬化ノボラック 樹脂繊維が得られる。一般に分子量 4000 以下のポリマー では紡糸が不可能とされている。余談であるが、この繊維 の発明者は繊維の専門家ではないと聞いている。恐らく繊 維の専門家であれば、この樹脂を緎維化しょうと考えな かったのではないかと考えると非常に興味深い。このよう に、たかだか分子量 1000 程度で直線性にそしく延伸によ る分子の配向も期待できないノボラック型フェノール樹脂 をあえて紡糸したものなので、この未硬化繊維は非常に強 度が弱い。これを慎重に硬化反応処理することによりカイ ノールが得られる。

カイノールは図 3 のような推定化学構造をしているが、 この他に図 4 で示されるような各種の構造がその分子中に 少量ながらも存在することが分っている。

\section{3. 性 質}

\section{1 カイノールの繊維特性}

カイノールはアモルファス、無配向の三次元構造を有す るため強度はあまり高くない。しかしながら表 1 に見られ るようにテキスタイル用繊維としての条件は満たしている。 繊維の色が金茶色をしているため染色に難はあるが、織物 や衣料にした場合の肌触りや着心地が良くウールに近い感 触を持っている。また、写真 1 にも見られるように形状は チョップドファイバー、ミルドファイバー、フィラメント ヤーン、スパンヤーン、クロス、フェルト、ペーパーなど 各種の形態で提供されている。

\section{2 防炎性・難燃性}

防炎性、難燃性の指標としての LOI (限界酸素指数)を他

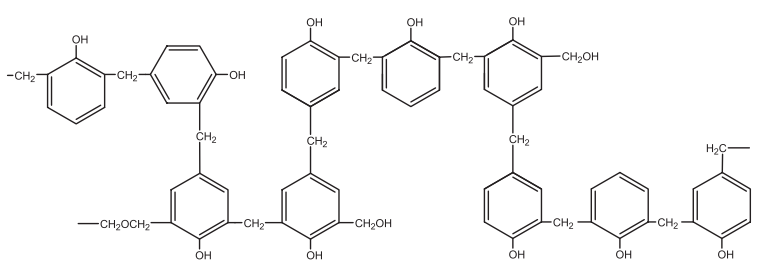

図 3 カイノールの推定化学構造

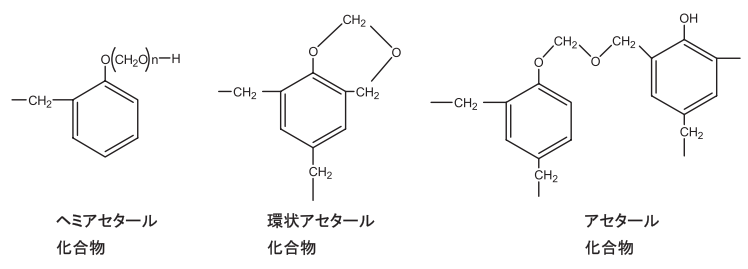

図4 カイノール中に少量見られる構造
表 1 カイノールの繊維特性

\begin{tabular}{|c|c|}
\hline 繊度 $(\mathrm{d})$ & 1.5 10 (羊毛 $\langle 3 \mathrm{~d}\rangle$ ) \\
\hline 繊維長 $(\mathrm{mm})$ & $1 \sim 100$ \\
\hline 引張強度 $(\mathrm{g} / \mathrm{d})$ & 1.3〜1.8(レーヨン、アセテート並み) \\
\hline 引張伸度 (\%) & 30〜70(一般合繊並み) \\
\hline 引掛伸度 $(\mathrm{g} / \mathrm{d})$ & 2.2〜3.1(アクリル並み) \\
\hline 結節強度 $(\mathrm{g} / \mathrm{d})$ & 1.1〜1.5(レーヨン、アセテート並み) \\
\hline 3(\%)伸長弾性率 (\%) & 92〜96(アクリル並み) \\
\hline 見掛けヤング率 $\left(\mathrm{kg} / \mathrm{mm}^{2}\right)$ & 350４50(アクリル、アセテート並み) \\
\hline 比重 & 1.27 (ガラス繊維の半分) \\
\hline 水分率 $(\%)\left(20^{\circ} \mathrm{C} 、 65 \% \mathrm{RH}\right)$ & 6(綿に近い) \\
\hline 染色性 & 分散染料、カチオン染料で染色可 \\
\hline 色相 & 金茶色 \\
\hline
\end{tabular}

写真 1 カイノール製品群

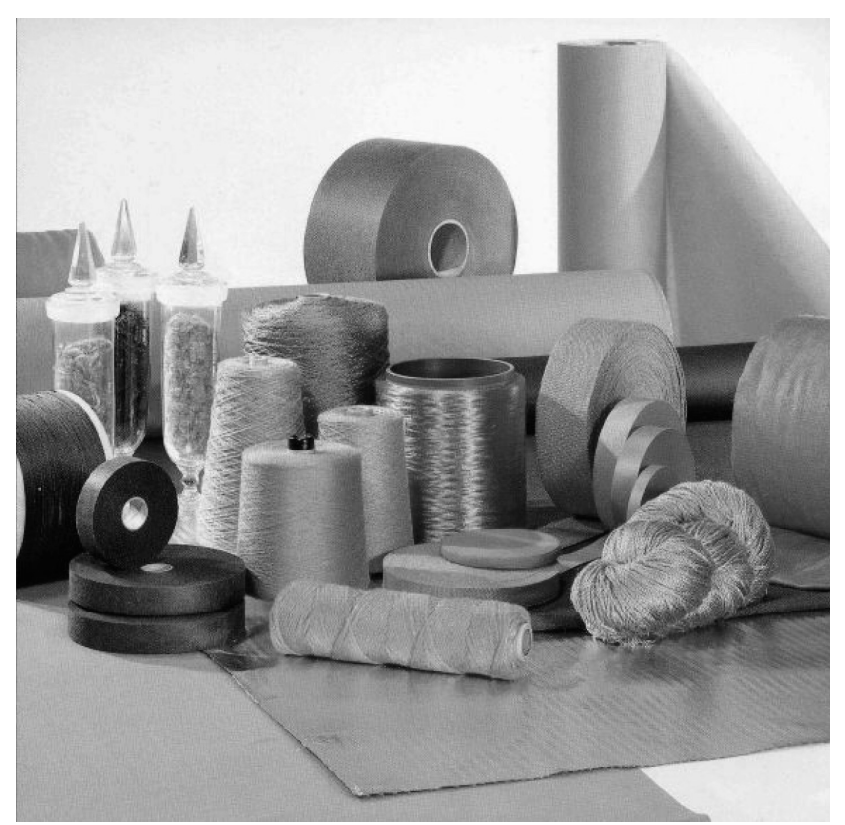

の繊維と比較して表 2 に、燃焼試験の結果を表 3 に示す。 カイノールは有機繊維の中でも高い LOI を有している。 燃焼試験の結果、燃え難く、収縮も極めて少ない。これら の特長はカイノールが非常に高い炭素含有率を持っている ことと、三次元網目構造を有している事などに起因してい るものと考えられる。

表 2 カイノールと他繊維の LOI 比較

\begin{tabular}{|l|c|}
\hline カイノール & $30 \sim 34(\%)$ \\
\hline アラミド & 28 \\
\hline モダクリル & 26 \\
\hline ポリエステル & 22 \\
\hline 綿 & 19 \\
\hline
\end{tabular}

表 3 燃焼試験(垂直法) (JIS-L-1091 による)

\begin{tabular}{|c|c|c|c|}
\hline & カイノール & 防炎加工木綿 & アラミド \\
\hline 残 炎 $(\mathrm{sec})$ & なし & なし & なし \\
\hline 余じん $(\mathrm{sec})$ & なし & なし & なし \\
\hline 炭化長 $(\mathrm{cm})$ & 1.1 & 8.2 & 2.6 \\
\hline 収縮長 $(\mathrm{cm})$ & 0.3 & 0.4 & 1.4 \\
\hline
\end{tabular}




\section{3 不融性}

カイノールは炎にさらされても高温下に置かれても溶融 する事が無く、その形のまま炭素化するだけである。火災 などによる火傷は衣服の溶融や収縮が原因になる場合が極 めて多いが、カイノールの防災服を使用すれば、その危険 性が低減できる。この不融性はカイノールが三次元構造を 有している事による。

\section{4 低発煙量・低毒性}

カイノールは燃焼させた場合の発煙量が非常に少ないと いう特長を持っている (図 5 参照)ので、火災により視界が 遮られるという危険が少なくなる。また、カイノールの構 成元素は木綿と同じ様に炭素と水素と酸素のみであり、ハ ロゲン、リン、窒素などの有毒ガスの原因となる元素は含

\section{- Smoke Emission}

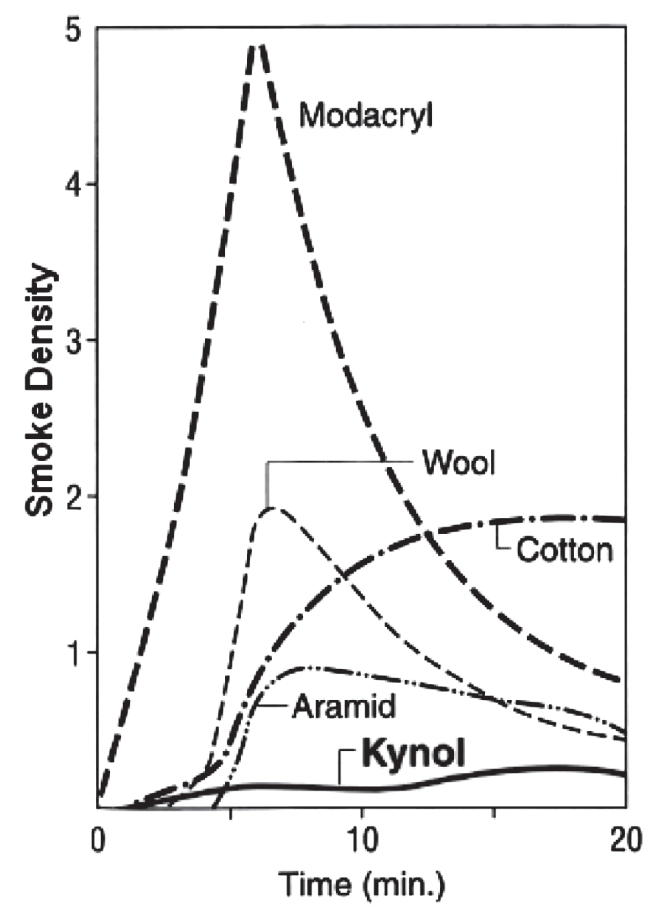

図 5 発煙性テスト

表 4 燃焼ガス・毒性マウス試験

(日本建築センター法による)

\section{- Mouse Test for Toxicity of Combustion Gases}

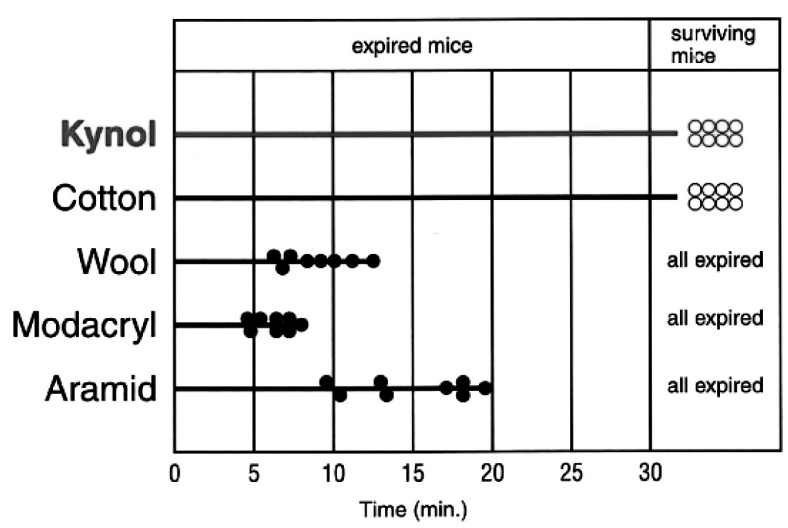

まれていない。従って、表 4 に示されるように燃焼ガスの 毒性は木綿と同様、極めて低い。

\section{5 耐熱性}

耐熱性あるいは耐熱温度というものは目的や用途により 異なるので、一概には論じられないが、カイノールの TG 測定(図 6)からは以下のようになる。減量開始温度は空気 中で $200^{\circ} \mathrm{C}$ 近辺であり窒素中では $250 \sim 300^{\circ} \mathrm{C}$ である。カ イノールを長時間高温処理した場合の強力保持率などを図 7 に示したが、実質的な強力低下は空気中で $200^{\circ} \mathrm{C}$ である。 処理時間が短い時点では強力は逆に上昇する。このことは 以前、カイノールの分子中の未架橋部分が熱処理により架 橋構造へ変化するためであるとされていたが、その他に酸 素架橋も生じている事が近年明らかになった。

\section{6 断熱性}

カイノールは熱伝導性が低く(表 5 参照)、良好な断熱性 を有している。カイノールの断熱性は、繊維そのものと、 それを取り巻く媒体としての空気の熱伝導によるため、形 状に大きく影響される。一般にはフェルトが最も断熱性が 高く、織布、ペーパーの順に低くなる。またカイノールに は極低温にさらされても脆化しないという特長もある。表 6 に極低温試験の結果を示した。このデー夕は極低温に所 定時間カイノールを保持した直後に測定したものであるが、 強度、伸度ともに変化なく、その抵抗力が優れている事が 分る。

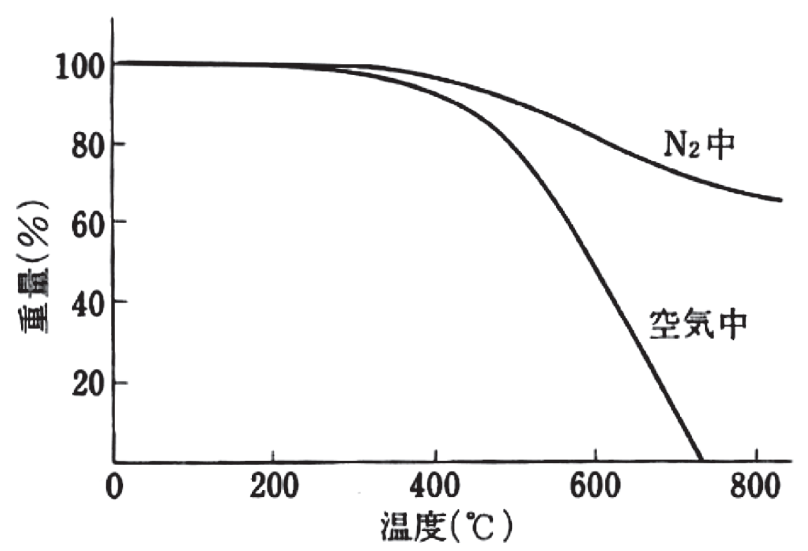

図 6 カイノールの TG 曲線

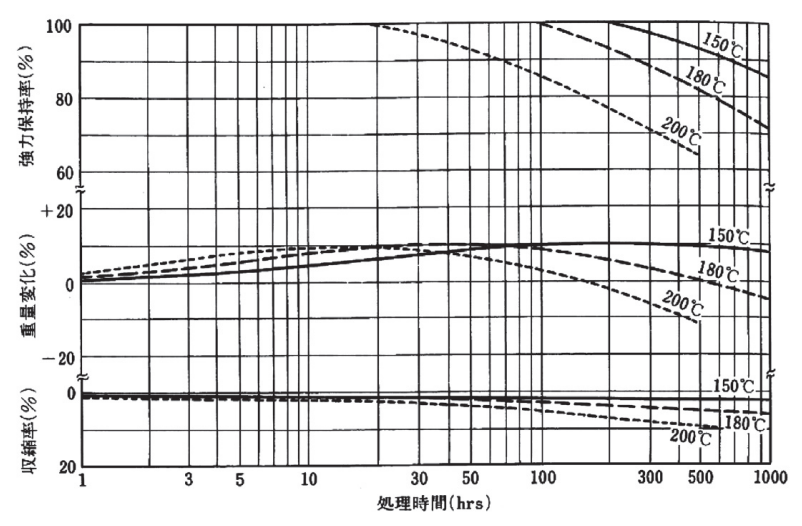

図 7 空気中における耐熱特性 
表 5 断熱性テスト

\begin{tabular}{|c|c|c|c|c|}
\hline \multirow{2}{*}{ 断熱材の種類 } & 項目 & かさ密度 & 温 度 & 熱伝導率 \\
\cline { 2 - 5 } & 単位 & $\mathrm{g} / \mathrm{cm}^{3}$ & ${ }^{\circ} \mathrm{C}$ & $\mathrm{kcal} / \mathrm{m} \cdot \mathrm{h} \cdot{ }^{\circ} \mathrm{C}$ \\
\hline カイノールフェルト & 0.01 & -40 & 0.024 \\
\hline カイノールフェルト & 0.01 & 20 & 0.035 \\
\hline カイノールフェルト & 0.01 & 40 & 0.039 \\
\hline ガラス 繊 維 & 0.04 & 20 & 0.035 \\
\hline ガラスウール & 0.06 & 20 & 0.036 \\
\hline ロックウール & 0.10 & 20 & 0.032 \\
\hline
\end{tabular}

※ASTM C-117 法 DYNATECH 社(米国)測定
表 6 極低温テスト

\begin{tabular}{|c|c|c|}
\hline 処理条件 項 & 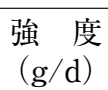 & $\begin{array}{c}\text { 伸 度 } \\
(\%)\end{array}$ \\
\hline 未処理 & 1.34 & 34 \\
\hline$-44^{\circ} \mathrm{C}$ & 1.39 & 47 \\
\hline$-139^{\circ} \mathrm{C}$ & 1.30 & 39 \\
\hline$-196^{\circ} \mathrm{C} \times 6 \mathrm{~h}$ & 1.36 & 40 \\
\hline
\end{tabular}

表 7 耐薬品性テスト

\begin{tabular}{|c|c|c|c|c|c|c|c|c|}
\hline & \multirow{2}{*}{$\begin{array}{c}\text { 濃 }(\%) \\
(\%)\end{array}$} & \multirow{2}{*}{$\left.{ }^{\left({ }^{\circ} \mathrm{C}\right)}\right)^{\text {度 }}$} & \multirow{2}{*}{$\begin{array}{c}\text { 時 間 } \\
\text { (hrs) }\end{array}$} & \multicolumn{5}{|c|}{ 強 力 低 下 度*** } \\
\hline & & & & なし & わずか & 中 & 明らか & 崩壊 \\
\hline 塩酸 & 10 & 20 & 100 & O & & & & \\
\hline 塩 酸 & 10 & 98 & 8 & $\bigcirc$ & & & & \\
\hline 塩 酸 & 36 & 20 & 100 & $\bigcirc$ & & & & \\
\hline 硫酸 & 60 & 20 & 100 & $\bigcirc$ & & & & \\
\hline 硫酸 & 60 & 98 & 8 & O & & & & \\
\hline 硫酸 & 96 & 20 & 100 & $\bigcirc$ & & & & \\
\hline 硫酸 & 96 & 98 & 8 & $\bigcirc$ & & & & \\
\hline 硫 酸 & 96 & 150 & 8 & & $\bigcirc$ & & & \\
\hline 硝酸 & 10 & 20 & 100 & $\bigcirc$ & & & & \\
\hline 硝酸 & 10 & 98 & 8 & & & & 0 & \\
\hline 硝 酸 & 60 & 20 & 100 & & & O & & \\
\hline フッ 酸 & 7 & 80 & 5 & O & & & & \\
\hline フッ 酸 & 15 & 50 & 40 & O & & & & \\
\hline アンモニア水 & 28 & 20 & 100 & O & & & & \\
\hline 水酸化ナトリウム & 10 & 20 & 100 & O & & & & \\
\hline 水酸化ナトリウム & 10 & 98 & 8 & & 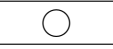 & & & \\
\hline 水酸化ナトリウム & 40 & 20 & 100 & & 0 & & & \\
\hline 水酸化ナトリウム & 40 & 98 & 8 & & 0 & & & \\
\hline ベンゼン & 100 & 20 & 100 & $\bigcirc$ & & & & \\
\hline ベンゼン & 100 & $80 \% *$ & 8 & $\bigcirc$ & & & & \\
\hline メタノール & 100 & 20 & 100 & O & & & & \\
\hline メタノール & 100 & $65 \% *$ & 8 & O & & & & \\
\hline アセトン & 100 & 20 & 100 & $\bigcirc$ & & & & \\
\hline アセトン & 100 & $56 \% *$ & 8 & O & & & & \\
\hline 酢 酸 & 100 & 20 & 100 & O & & & & \\
\hline 酢酸 & 100 & $119 \% *$ & 8 & O & & & & \\
\hline 四塩化炭素 & 100 & 20 & 100 & O & & & & \\
\hline 四塩化炭素 & 100 & 77 * & 8 & O & & & & \\
\hline
\end{tabular}

※重量パーセント

※各溶剤の沸点

※※なし…強力保持率 100～91\% わずか...強力保持率 90～76\%

中 $\cdots$ 強力保持率 $75 \sim 56 \%$ 明らか...強力保持率 $55 \sim 21 \%$ 崩壊...強力保持率 $20 \sim 0 \%$

\section{7 耐薬品性}

カイノールはフェノール樹脂がそうであるように、酸化 性の強酸と強アルカリには抵抗力が低い。しかしながら フッ酸をはじめとするその他の強酸や、有機溶剤には優れ た耐性を示す(表 7 参照)。さらに、繊維工業や紙・パルプ 業界、食品工業関係などで使用される漂白剤に対しても表 8 で示されるように、良好な耐性を示す。その他、水蒸気 による劣化も極めて少なく、カイノールの耐薬品性は非常 に優れたものである。このような特長は三次元に架橋した
網目構造と加水分解を受けにくい化学構造に由来するもの である。

\section{8 その他の特長}

フェノール樹脂は電気絶縁性に優れているが、カイノー ルも同様に絶縁性を有している。また、吸音性や遮音性が 良好であり、カイノールフェルトやカイノールマットはウ レタンフォームやガラスウールマットよりも吸音率が高い。 その他、各種の樹脂やゴムとの親和性が良いという特長を 
表 8 カイノールおよび各種特殊繊維の耐漂白剂性

○…保持率が 95\% 以上 $\bigcirc \cdots$ 保持率が 94 85\% $\triangle \cdots$ 保持率が $84 \sim 70 \%$

$\times \cdots$ 保持率が $69 \sim 30 \% \times \times \cdots$ 保持率が $29 \%$ 以下

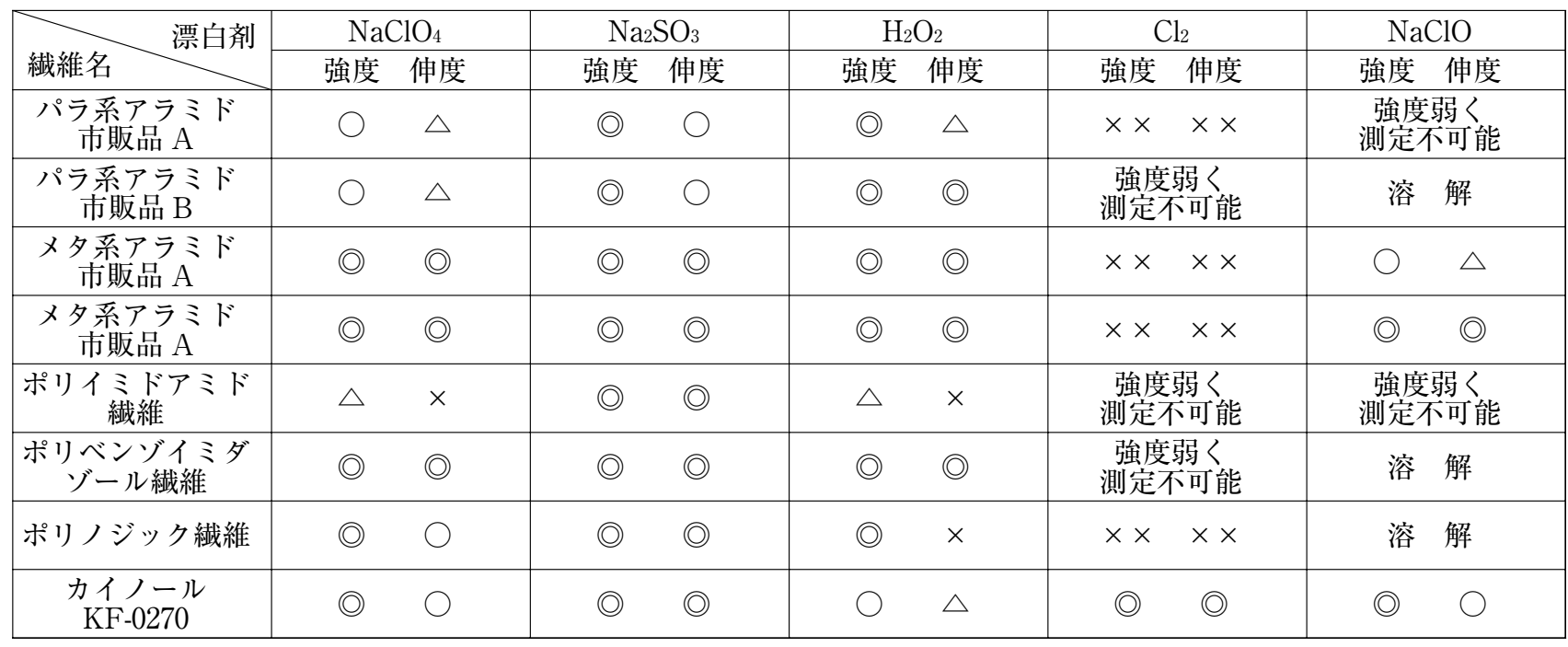

$\begin{array}{llll} & & \text { (濃度) } & \\ \mathrm{NaClO}_{4} & \text { 過塩素酸ナトリウム } & 50 \% & \\ \mathrm{Na}_{2} \mathrm{SO}_{3} & \text { 带硫酸ナリリウム } & 10 \% & \\ \mathrm{H}_{2} \mathrm{O}_{2} & \text { 過酸化水素 } & 35 \% & \\ \mathrm{Cl}_{2} & \text { 塩素水 } & \text { 有効塩素 } & 0.3 \% \\ \mathrm{NaClO} & \text { 次带塩素酸ナトリウム } & \text { 有效塩素 } & 12 \%\end{array}$

(室温にて 100 時間浸漬)

持っている。これはカイノールがその分子中に多くの極性 基を持っていることによる。また比重が低く、アモルファ スであること事から、軽量で柔らかい風合いを有している。

\section{4. カイノールからの炭素繊維}

不融性で、しかも炭素含有率の高いカイノールは、炭素 繊維用プリカーサーとしても優れている。硬化されたフェ ノール樹脂を炭素化した場合、固相炭素化を経るため収縮 はある程度あるものの、ほぼそのままの形状の炭素化物が 得られる。これと同様にカイノール䋊維も任意の形状、フェ ルト、クロス、ペーパーなどに加工した後に炭素化を施す 事によりこれらの形状の炭素化物が容易に得られる。これ はその他の炭素繊維には無い特長である。

表 9 にカイノールからの炭素繊維とその他の炭素繊維の
特性を比較したデータを示す。このデータからもわかると おり、カイノールからの炭素繊維はローモジュラスタイプ である。これはフェノール樹脂の炭素化物がアモルファス 構造であるのと同様にカイノールからの炭素繊維もアモル ファス構造であるため無配向である事が原因である。この ため引張強度や弾性率は低くなるが、その代わりに柔軟性 があり相手攻撃性が低い。これらの特長を生かしてグラン ドパッキンなどに利用されている。

\section{5. カイノールからの活性炭素繊維}

フェノール樹脂の炭素化物はアモルファス構造であるた め表面に活性点が多く、水蒸気等で賦活する事で容易に活 性炭が得られる。しかもその細孔はマイクロポア(直径 $20 \AA ̊$ 以下)が主体である。これはフェノール樹脂炭素化物

表 9 カイノール炭素繊維の特性

\begin{tabular}{|c|c|c|c|}
\hline \multirow{2}{*}{ 比重 } & カイノール系 & アクリル系 $(\mathrm{A}$ 社) & ピッチ系 (B 社) \\
\hline & $1.4 \sim 1.6$ & $1.7 \sim 1.8$ & $1.6 \sim 1.7$ \\
\hline 繊維径 $(\mu \mathrm{m})$ & $11 \sim 12$ & $7 \sim 8$ & $12 \sim 14$ \\
\hline 引張強度 $\left(\mathrm{kg} / \mathrm{mm}^{2}\right)$ & $50 \sim 70$ & $200 \sim 250$ & 80 \\
\hline 引張弾性率 $\left(\mathrm{kg} / \mathrm{mm}^{2}\right)$ & $2,000 \sim 3,000$ & $20,000 \sim 30,000$ & $3,000 \sim 3,500$ \\
\hline 炭素含有率 (wt\%) & 94.0 & 92.6 & 95.3 \\
\hline TG 減量開始温度 $\left({ }^{\circ} \mathrm{C}\right)$ & 430 & 486 & 416 \\
\hline \multicolumn{4}{|l|}{ 空気中の重量減少率 (wt\%) } \\
\hline $350^{\circ} \mathrm{C} \times 350 \mathrm{hr}$ & 0 & 0 & 0 \\
\hline $400^{\circ} \mathrm{C} \times 350 \mathrm{hr}$ & 2.8 & 2.4 & 3.1 \\
\hline $\mathrm{X}$ 線回折角 002 面 $2 \theta\left(^{\circ}\right)$ & 23 & 25 & 24 \\
\hline 電気比抵抗 $\left(\times 10^{-5} \Omega \cdot \mathrm{cm}\right)$ & $1,000 \sim 3,000$ & $800 \sim 1,000$ & $2,000 \sim 3,000$ \\
\hline 耐薬品性(有機•無機) & (a) & $\bigcirc$ & $\bigcirc$ \\
\hline
\end{tabular}


の炭素化構造に起因すると考えられるが、これらの事から 大表面積な活性炭が容易に得られる。これと同様にカイ ノールからも大表面積な活性炭素繊維を容易に得る事が出 来る。しかも、前述の通り炭素化段階で任意の形状が得ら れるため、フェルト、クロス、ペーパーなどの形状の活性 炭素繊維を容易に得る事が出来る。これも他の活性炭素繊 維には無いカイノール独自の特長である。

カイノールからの活性炭素繊維はマイクロポアが主体で あるため、粒状活性炭と比べ吸脱着速度に優れ、また吸着 量も多い(表 10 参照) 為、急速吸着を必要とする場合や充 填する装置の軽量化などに優位性がある。また表 10 に示 したように比表面積が大きいにも関わらず引張強度が高い のがカイノール活性炭素繊維の特長であり、したがって使 用時の炭塵の発生も少ない。

\section{6. カイノールの用途}

カイノール用途分野は大別すると次の 5 分野となる。

(1)防災安全 (2)電線材料 (3)石綿代替 (4)炭素䋊維

(5)活性炭素繊維

分野別に現状を説明すると、次の通りである。

(1)防災安全

この分野ではカイノールの防炎性、難燃性、耐熱性、不 融性、さらには収縮が少なく炭化するのみである特長を生 かし、次のような用途で使用されている。

- 船舶耐熱服

・重工業作業服

・防災安全フード

しかしながら、カイノールは繊維強度、染色性等に難点 があり、一部の特殊用途を除き規模の大きな汎用品市場に はなかなか入り込めていない。一方、欧米においては防災 規制が強化されてきており、新たな用途として FBL(Fire Blocking Layer)が有望と思われる。この用途においてカ イノールを展開するためには、前述のカイノールの欠点を 補い、且つカイノールの特長を発揮させるために、他繊維 との複合化が有効と考えている。

\section{(2)電線材料}

この分野ではカイノールの耐熱性・不融性、低発煙量・ 低毒性である特長を生かし、次のような用途で使用されて いる。

・ケーブル延焼防止用塗料、パテ

・ケーブル介在糸

ケーブル介在糸用途においては、カイノールの放射線に よる劣化が少ないという特長を活かし、原子力関連設備用 のケーブル介在糸として使用されている。

\section{(3)石綿代替}

用途には摩擦材、シール材の 2 つがある。

摩擦材としてはクラッチペーパー、ディスクブレーキな どがある。

これは、カイノールの耐熱性、柔軟性、また樹脂との親 和性が良好であるという点を利用したものである。

シール材としては、グランドパッキン、ガスケットなど がある。これは、カイノールの耐熱性、耐薬品性を利用し たものである。

\section{(4)炭素繊維}

前述のように、カイノールは加工した形状のまま容易に 炭素化することが可能である。このため、クロス、フェル ト状にあらかじめ加工して、これらを焼成した炭素繊維製 品を得ることができる。

物性面では、カイノール炭素繊維は、低強力・低弾性で ある。よって構造材料用途には不向きである。しかし、耐 熱性、耐薬品性などの面においては他の炭素繊維と遜色が ない。また柔軟性に富んでおり加工性が良い。さらには相 手攻撃性(基材を痛めない、チクチクしない)が他の炭素繊 維に比べて非常に少ない。この事と上記の加工性を特長と して、現在は次のような用途で使用されている。

・グランドパッキン

・アブレーション材

・断熱材

表 10 カイノール活性炭素繊維の特性

\begin{tabular}{|c|c|c|c|c|}
\hline 項 目 種 類 & $\begin{array}{c}\text { カイノール系 } \\
\text { GCI }\end{array}$ & $\begin{array}{c}\text { レーヨン系 } \\
\text { A 社 }\end{array}$ & $\begin{array}{l}\text { アクリル系 } \\
\text { B 社 }\end{array}$ & $\begin{array}{c}\text { 粒状炭 } \\
\text { C 社 }\end{array}$ \\
\hline 繊維径( $(\mu \mathrm{m})$ & $9 \sim 11$ & $15 \sim 20$ & 68 & \\
\hline 比表面積 $\left(\mathrm{m}^{2} / \mathrm{g}\right)$ & $1,500 \sim 2,000$ & 1,400 & 900 & 800 \\
\hline 細孔径 $(\AA)$ & $15 \sim 35$ & 14 & 10 & $15 \sim 25$ \\
\hline 引張強度 $\left(\mathrm{kg} / \mathrm{mm}^{2}\right)$ & $30 \sim 40$ & $50 \sim 10$ & 30 & \\
\hline 引張弾性率 $\left(\mathrm{kg} / \mathrm{mm}^{2}\right)$ & $1,000 \sim 1,500$ & & $7,000 \sim 8,000$ & \\
\hline 水道水 $\mathrm{Cl}_{2}$ 除去率 (\%) & $90 \sim 100$ & & & $20 \sim 30$ \\
\hline $\begin{array}{l}\text { メチレンブルー脱色力 } \\
(\mathrm{ml} / \mathrm{g})\end{array}$ & $310 \sim 380$ & & $100 \sim 150$ & $70 \sim 80$ \\
\hline $\begin{array}{l}\text { 中間分子量物吸着速度 } \\
(\ell / \mathrm{g} \cdot \mathrm{hr})\end{array}$ & $2 \sim 8$ & $1 \sim 2$ & 0.5 & 0.2 \\
\hline
\end{tabular}




\section{(5)活性炭素繊維}

一般的に活性炭素繊維は粒状活性炭に比べ接触効率が高

く、吸着速度が速い、また吸着容量が大きい。これらのこ とにより䋊維状活性炭を使用した製品には次のような特色 が生まれてくる。

・吸着装置を小型化できる。

・粒状活性炭では出来なかった高度技術製品が可能 活性炭素繊維のプリカーサーとしては、カイノールの他 に、レーヨン系、ピッチ系、アクリル系などがあるが、カ イノール系は高比表面積の活性炭が得やすいこと、および 高強度の活性炭素繊維が得られるという優位性がある。

用途としては、主に吸着材料と電子・電極材料の二つの 用途がある。

吸着材としては次のようなものがある。

・溶剤回収装置

- 浄水器

- 空気清浄機

・マスク

- 家庭用脱臭材

·衛生材料

電子・電極材としては、電気二重層キャパシタの電極板 として使用されている。

以上のように様々な分野で使用されているカイノールで あるが、更に活躍の場を広げたいと考えている。そのため には、繊維強度、染色性などの弱点を補いつつ、カイノー ルの優れた特長を活かす方法、すなわち他素材との複合化 が必要と考えている。これを実現し、市場のより高度な要 求に対応し、更なる飛躍を遂げたいと考えている。

\section{7. おわりに}

カイノールは誕生してから約 40 年、本格的に工業化さ れてからも約 25 年経過している。しかしながら、存外、 世間の認知度は低く、特に海外、東・東南アジア地域では 殆ど知られていない。これはカイノールが一般合繊等とは 異なり産業資材、それもごく限定的な用途にしか利用され ていないことと、フェノール樹脂繊維が世界的に見ても現 在では群栄化学工業(株しか製造・販売していない事も一因 であると考えられる。今後、市場及びものづくりの現場が 加速的にさらに海外にシフトしていく事を考えると、更に 認知度を上げていかなければならないと考える。それを考 えると本稿が、カイノールの潜在未開拓分野、及び市場の 展開の一助となれば望外の喜びである。

\section{参考文献}

1）小山裕章：赤外線吸収スペクトル法によるフェノール 系繊維の硬化機構の研究、第 25 回熱硬化性樹脂講演 討論会要旨集、p.32(1975).

2) 宮下雄次 : 耐熱フェノール繊維「カイノール」工業 材料、31(6), p.52(1983).

3）藤居良助：フェノール系繊維「カイノール」、日工マ テリアル、10, p.36(1984).

4）小形文麿：フェノール系ノボロイド繊維「カイノー ル」の新用途、工業材料、34(13), p.93(1987).

5）松本義一：カイノール、バウンダリー、3(1), p.20 (1987). 